\title{
Eco-environmental Changes of Wetland Resources of Hakaluki haor in Bangladesh Using GIS Technology
}

Uddin $\mathbf{M J}^{1 *}$, Mohiuddin ASM ${ }^{1}$, Hossain $\mathbf{S T}^{2}$ and Hakim $\mathrm{A}^{3}$

${ }^{1}$ Department of Soil, Water and Environment, University of Dhaka, Bangladesh

${ }^{2}$ Friends in Village Development, Bangladesh (FIVDB)

${ }^{3}$ Department of Soil Science, University of Chittagong, Bangladesh

\begin{abstract}
Bangladesh is traversed by numerous rivers and it comprises most of the delta of three great rivers- the Ganges, the Brahmaputra and the Meghna. Specifically, the greater part of northeast region is taken up by the wetland basin and is characterized by the presence of numerous large, deeply flooded depressions, known as haors, between the rivers where Hakaluki haor is one of them. A study was conducted using the soil and landform information of 1985 and 2003 of Hakaluki haor wetland ecosystem. Areas of soil boundaries between 1985 and 2003 were estimated using polygon attribute tables (PAT) files which revealed that this wetland ecosystem has been decreasing at an alarming rate due to sedimentation from the surrounding hilly areas. These estimates were verified using the land type information because soil boundaries and land types are the inter-related issues. Besides, a soil profile study also revealed that a buried horizon formed beneath the plow layer which signifies the sedimentation. Thus, the wetland ecosystem degradation seriously affects the bio-resources of the study sites. A sustainable technology should be adopted to prevent the degradation of hilly lands and conservation and caring of soil resources in the basins.
\end{abstract}

\section{Keywords: Hakaluki haor; Wet land resources; GIS Technology}

\section{Introduction}

Wetlands are considered as invaluable components of the ecosystems with economic, ecological and commercial perspectives. The fresh water wetlands of Bangladesh support a wide variety of floral and faunal diversity, some of which are globally as well as locally endangered. However, these aquatic resources have been subjected to rapid degradation due to the increasing population pressure, habitat destructions and other anthropogenic as well as natural causes [1]. Bangladesh is a country of vast wetland resources and has been estimated to have at seven to eight million hectares, which is about fifty percent of the country's land surface. The greater part of the northeast region consists of wetland basins and is characterized by the presence of numerous large, deeply flooded depressions, known as haors, between the rivers. Wetland haors are the important carrier of unique biodiversity which are considered as the most productive resources of Bangladesh. The geology, hydrology, soil characteristics, and socioeconomic attributes of the haor basin, also contributes to distinguish it from its adjacent hilly land. It is believed that the basin is technically active and is undergoing subsidence [2]. During monsoon the basin receives the huge discharges of large number of rivers flowing down from the hills of Assam and Meghalaya and takes the form of a vast inland sea. According to World Resource Institute [3] Sylhet basin covers a large number of haors and wetlands like Hakaluki haor, Tanguar haor, Hail haor etc. The haor basin is an extensive alluvial plain supporting a variety of wetland habitats. It contains about 47 major haors and more than 6,000 beels, or freshwater lakes, nearly half of which are seasonal [4]. The major rivers in the study area are the Surma and the Kushiyara and their tributaries are Manu, Khowai, Jadukhata, Piyain, Mogra, Mahadao and Kangsha which form the dense drainage network of the haors. These hilly rivers are coming down from the Khasia and Jaintia hills in Meghalaya. They carry particularly high volumes of water with sediments as they come from some of the rainiest places in the world. Thus, the wetlands as well as their bio-resources are being drastically reduced due to recent climate change and human interferences.

\section{Problem Statement}

Hakaluki haor is a very resourceful habitat for various types of wetland flora and fauna. Due to human and natural interference, the habitat deteriorates much and has lost its real structure for the last few decades. Many of the flora and fauna along with wildlife and migratory bird species are decreasing rapidly in the area. The people living in and around the Hakaluki haor area are creating several types of environmental problems regarding natural resources depletion. The major problems are as follows: Siltation is a major problem in the waterways of Hakaluki haor. Juri and Sonai are major sources of silt of this haor. This is also notable that Sonai and its nearby canals carry silts from the Kushiyara River. The Juri River carries huge quantity of silts from the hills of upstream. The major siltation is going on in the southeast and northwest directions of the haor. The siltation causes consumption of land for settlement and cultivable lands that cause reduction of natural biological production of many wetland flora and fauna. All the waterways are at least partially affected by the flood water that causes siltation and fills up the depth of water bodies. Once the depth is lessened due to siltation, the carrying capacity of water bodies become reduced, which hampers its multidimensional ways in the development of the area. Siltation and over exploitation of wetland vegetation for food and fodder are the causes of degradation of aquatic vegetation. A major cause of depletion of genetic resources is conversion of wetlands to rice fields. The study sites were also rich with its various types of swamp vegetations even couple of decades back. Due to conversion of wetlands to cultivable lands, settlement and fuel wood collection, the swamp forest and its biodiversity are in danger. Now, in the dry season, people living in and around the haor are destroying stems of swamp trees to meet fuel wood requirement and

*Corresponding author: Uddin MJ, Department of Soil, Water and Environment, University of Dhaka, Bangladesh, E-mail: mjuddin66@yahoo.com

Received May 06, 2013; Accepted May 28, 2013; Published June 11, 2013

Citation: Uddin MJ, Mohiuddin ASM, Hossain ST, Hakim A (2013) Ecoenvironmental Changes of Wetland Resources of Hakaluki haor in Bangladesh Using GIS Technology. J Biodivers Endanger Species 1:103. doi:10.4172/

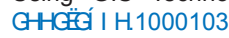

Copyright: ( 2013 Uddin MJ, et al. This is an open-access article distributed under the terms of the Creative Commons Attribution License, which permits unrestricted use, distribution, and reproduction in any medium, provided the original author and source are credited. 
business, which enhance the erosion of the haor. With the reduction of swamp forests, migratory birds and other wildlife species are losing habitat for living and spawning, which causes degradation of biological production.

During the last few decades, agricultural activities have been expanded in the wetland area very rapidly which has affected the wetland ecosystems adversely both in qualitative and quantitative aspects. Human activities related to farming in the wetlands during winter months cause disturbance to the migratory birds. The increasing human settlement is another problem for the haor ecosystem which is not only has occupied the natural habitat but also has disturbed the wildlife greatly in the area. The biodiversity and biological production of the Hakaluki haor are declining situations for the last couple of decades. Siltation, over-exploitation of natural resources, improper use of agrochemicals and other natural and man-made interruptions are the causes for these depletions, which result scarcity of food, fuel, fodder, degradation of habitat and poverty. Due to loss of natural habitat, various types of fishes, birds, mollusks, wildlife and vegetation are unable to survive and thus it is causing scarcity of food, housing materials and fuel wood in the area. Siltation is one of the major causes for water congestion. Unplanned cross dam/embankment, conversion of land use pattern cause water congestion. This water congestion results loss of agricultural products due to early flood.

The main objective of this paper is to investigate the ecoenvironmental changes of the Hakaluki haor, one of the major wetland resources of Bangladesh using GIS technology.

\section{Materials and Methods}

\section{Study site}

Hakaluki haor, locates in the North-East of Bangladesh (lies between North latitude $24^{\circ} 35^{\prime}$ to $24^{\circ} 44^{\prime}$ and East longitude $92^{\circ} 00^{\prime}$ to $92^{\circ} 08^{\prime}$ ) is the largest haor in South Asia and one of the most important fish and bird sanctuaries supporting around 1,90,000 people for their livelihood. The study site comprise mainly of wetlands, surrounding hillocks, reserve forests, planted forest and tea garden etc. It was designated as an Ecologically Critical Area (ECA) and recognized as one of the RAMSAR site of international importance for the conservation and sustainable utilization of wetlands. It is a wetland haor of shallow basin between the Patharia and Madhab hills in the East and the Bhatera hills to the West. It is made up of more than 276 small interconnecting beels, some of which are perennial and others are seasonal [5].

\section{Environmental settings of the study area}

The climate of the study sites is greatly influenced by the onset and withdrawal of the annual monsoon, four distinct seasons are recognized. These are: Pre-monsoon season which extends from April to May and is characterized by the increasing rainfall. Monsoon season which spreads over from the period June to September and is characterized by heavy rainfall occurring over longer duration. Post-monsoon season which extends from October to November and is characterized by decreasing rainfall. Dry season which extends from November to March and is characterized by little or no rainfall (Table 1). Only 3 to 4 percent of the total rainfall occurs during this season. Above all, the present situation is somehow different due to irregular rainfall pattern in the study sites. These are the scenarios of present climate change in the study sites. A scenario on temperature, wind velocity, sunshine hours, relative humidity and evapo-transpiration for the study sites have been presented in Table 1.

Hakaluki haor lies within the Sylhet trough, one of the major tectonic structures of Bangladesh. The basement of the trough slopes northwards at great depth, and passes beneath the Shilong Plateau, from which the Dauki Fault separates it. As a result of northward thrusting of the trough basement beneath the plateau, the Plateau is rising and the trough is subsiding. Tectonic subsidence during the Pliocene/Pleistocene period has been estimated at $2 \mathrm{~cm} /$ century, and this rate is considered still applicable. The great thicknesses of sediments, which have accumulated in the trough, have amplified the tectonic subsidence. It has been estimated that this subsidence was 4.5 $\mathrm{cm} /$ century during the Pliocene/Pleistocene, but this rate is no longer applicable. Based on the present sediment budget of the trough, it is considered that the present rate of sedimentary subsidence is $3.0 \mathrm{~cm} /$ century, and the present rate of total subsidence is thus thought to be 5.0 $\mathrm{cm} /$ century. The vast thickness of sediments filling the Sylhet trough were folded in the Late Miocene period to form the lndo-Burman ranges, a sequence of north-trending anticlines extending from $91^{\circ} 00$ east longitude eastwards into Myanmar. The anticlines increase in amplitude eastwards, and plunge northwards into the trough where they are submerged beneath the more recent sediments. In the north, however, the submerged portions of the anticlines have been detected by both seismic and geomagnetic surveys [6].

The river system of the northeastern corner of Bangladesh have played a very significant role in shaping the physical characteristics of Hakaluki haor. The Kushiyara river flows by the northern boundary of the study sites. The two main rivers, namely the Sonai-Bardal river enters the wetland haor from the east and the juri river from the southeast. A smaller river, namely the phanai river enters wetland haor from the Southwest. Besides, these a large number of smaller hilly streams enter the study site from the surrounding hills. The water levels inside Hakaluki haor are governed by the water levels in the Kushiyara

\begin{tabular}{|c|c|c|c|c|c|c|c|c|}
\hline \multirow[b]{2}{*}{ Months } & \multicolumn{3}{|c|}{ Temp ${ }^{\circ} \mathrm{C}$} & \multirow[t]{2}{*}{ Rainfall (mm) } & \multirow{2}{*}{$\begin{array}{l}\text { Wind velocity } \\
(\mathrm{m} / \mathrm{sec})\end{array}$} & \multirow{2}{*}{$\begin{array}{l}\text { Sunshine } \\
\text { (hours)* \% }\end{array}$} & \multirow{2}{*}{$\begin{array}{l}\text { Relative humidity } \\
\text { Mean } \%\end{array}$} & \multirow{2}{*}{$\begin{array}{l}\text { Evapo-transpiration } \\
\qquad(\mathrm{mm})\end{array}$} \\
\hline & Max & Min & Mean & & & & & \\
\hline January & 24.8 & 11.9 & 18.4 & 00 & 0.3 & 88.6 & 76 & 105.6 \\
\hline February & 27.2 & 14.0 & 20.6 & 00 & 0.4 & 85.7 & 69 & 124.4 \\
\hline March & 30.7 & 17.8 & 24.3 & 00 & 0.8 & 76.7 & 65 & 162.4 \\
\hline April & 30.8 & 19.9 & 25.4 & 100 & 1.2 & 63.8 & 75 & 157.1 \\
\hline May & 30.6 & 22.8 & 26.7 & 140 & 1.0 & 52.7 & 81 & 153.4 \\
\hline June & 29.9 & 24.3 & 27.1 & 150 & 1.2 & 27.8 & 88 & 125.0 \\
\hline July & 30.6 & 24.9 & 27.8 & 120 & 1.1 & 32.7 & 87 & 125.1 \\
\hline August & 30.8 & 24.9 & 27.9 & 150 & 1.1 & 38.7 & 87 & 130.6 \\
\hline September & 30.9 & 22.4 & 26.7 & 100 & 0.7 & 45.5 & 86 & 121.5 \\
\hline October & 30.5 & 22.3 & 26.3 & 100 & 0.4 & 68.9 & 82 & 128.4 \\
\hline November & 28.4 & 17.0 & 23.2 & 00 & 0.4 & 85.1 & 78 & 114.5 \\
\hline December & 26.0 & 13.6 & 19.9 & 00 & 0.3 & 90.3 & 76 & 102.6 \\
\hline
\end{tabular}

Table 1: Climatic Data of the study site (Source: IUCN Bangladesh [1]) 
Citation: Uddin MJ, Mohiuddin ASM, Hossain ST, Hakim A (2013) Eco-environmental Changes of Wetland Resources of Hakaluki haor in Bangladesh

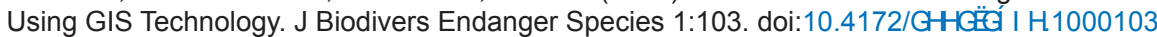

Page 3 of 4

river at the outfall of the Juri river. If the water levels in the Kushiyara river is lower those of Hakaluki haor, water flows from the study sites to the river. However, if the river stage is higher than that of the study sites, water flows into this wetland haor from the Kushiyara river as back flow.

\section{Methodology}

To complete the present research, different base materials were collected from different organizations. Topographic maps of Messers Capital Air Survey Ltd. Canada during 1974-75 and revised on the ground during 1982-83 and verified during 1987-88 and also 1989-90. In addition, aerial photo of 1984 was used for some verification. Other sources were used to verify it. The scale used for these data sources was 1:50,000. ESRI [7] developed ARC/GIS 8.1 software was used to prepare the digital databases on soil resources and land type. Land type categorization was done according to [8]. The areas of different soil boundaries along with other geographic features were estimated using the polygon attribute tables (PAT) files of the soil map of 1985 and 2003 $[9,10]$. A field study was conducted to find out sedimentation and other process of degradation of the wetland ecosystems.

\section{Results and Discussion}

It is important to note that a huge amount of sedimentation took place in the study sites. This phenomenon of sedimentation over a time periods introduces new soil boundaries along with high yielding rice crops which enhances the shrinkage of the water body. The sedimentation process is accelerated with the flow of upstream water from the surrounding hilly areas. As a result, Balaganj-Goainghat -Fagu soil association, Goainghat-Fagu, Goainghat-Fagu-Terchibari and Fagu-Terchibari-Hakaluki soil association emerges (Figure 1) where high yielding Boro rice cultivation is gaining popularity with ultimately shrinking the bio-resources of this wetland. The study revealed that the area covered by wetlands in the Hakaluki haor has been significantly reduced over the period from 1985 to 2003 (Figure 1). From Figure 1 (Superimposed soil map of 1985 and 2003), a GIS analysis using PAT (Polygon Attribute Tables) files revealed that total boundary of Hakaluki haor area was about 53, 215 ha, where river area was 562.20 ha, settlement was 1030.75 ha, main basin or water body was 4569.00 ha, and total soil boundaries was $47,053.00$ ha. Recently, the total soil boundaries has decreased to $25,182.00$ ha i. e. combining total of soil units 8-11 (Figure 1). The rate of reduction of the water body is about 46 percent. In the dry season, the area of the Hakaluki wetland haor shrink significantly which becomes 6405 ha. Regarding the intensity of the degradation of beels of Hakaluki haor, CNRS [11] and Khan[12] reported that due to sedimentation (silt carried by mainly the Juri and Sonai River from the surrounding hills or watershed area), many of the beels have been degrading at various levels. Compared to conditions in 1980, the proportion of degraded beels has increased from $10 \%$ of the total beel areas to more than $75 \%$ (Table 2), which have caused a steady decline in aquatic resources, which adversely impacted on the local communities.

In recent years, the basin soil area $(25,182.00 \mathrm{ha})$ is under rice cultivation using huge agrochemicals and ultimately serious effects on aquatic resources as well as bio-resources. From the land type map (Figure 2), the above estimation was verified. Land type is an important physical factors in determining the inundation flooding depth and also governs the utility aspects of land and soil resources [10]. The inundation land type conditions support the above finding that soil boundaries are decreasing due to the encroachment of sediments, settlements and infrastructure development in the wetland basins. The study also has showed that considerable changes occur in the depth of inundation due to sedimentation and other anthropogenic causes. This change has showed a positive impact on agricultural aspects enhancing emergence of new soil boundaries and serious negative impact on eco-environmental aspects i.e. degradation /reduction of wetland ecosystem. Uddin et al. [13] noted that when time series data were analyzed using GIS, an eco-environmental changes of Hail haor wetland resources took place in Bangladesh due to sedimentation. Similar findings were also shown by Hoq and Shoaib [8] and Sultana et al. [14]. Erickson et al. [15] also noted accretion of land for edaphic use in some flood prone areas of Bangladesh. Ullah et al. [16] conducted a study in the flood prone Mithamoin Upazila of Bangladesh observed
(A)

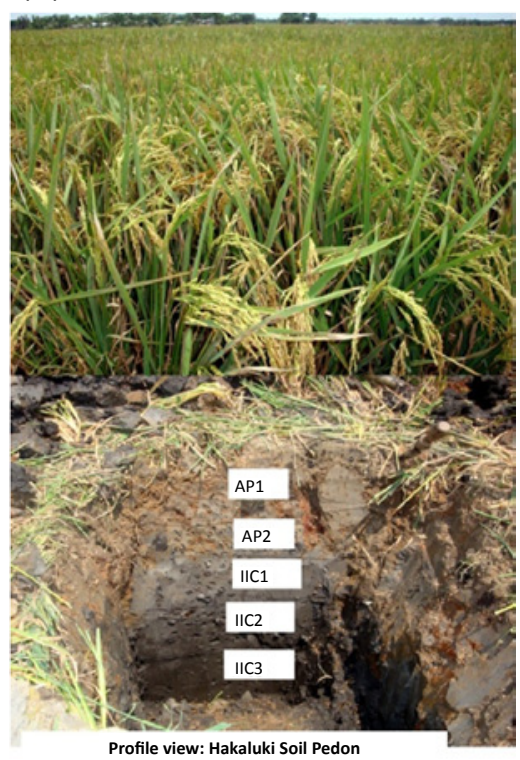

(B)

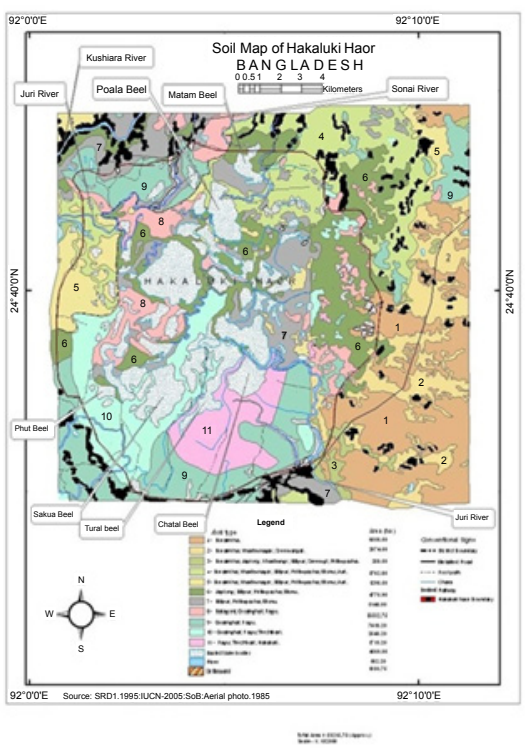

Figure 1(A\&B): Soil Map of Hakaluki Wetland Haor 
Citation: Uddin MJ, Mohiuddin ASM, Hossain ST, Hakim A (2013) Eco-environmental Changes of Wetland Resources of Hakaluki haor in Bangladesh Using GIS Technology. J Biodivers Endanger Species 1:103. doi:10.4172/2332-2543.1000103

Page 4 of 4

\begin{tabular}{|c|c|c|}
\hline Degradation rate (\%) & No. of Beels & Area (ha) \\
\hline $0-10$ & 87 & 2388.96 \\
\hline $11-25$ & 34 & 712.04 \\
\hline $26-50$ & 70 & 1268.13 \\
\hline $51-75$ & 25 & 538.24 \\
\hline Above 75 & 22 & 89.34 \\
\hline Total & 238 & 4996.71 \\
\hline
\end{tabular}

Table 2: Intensity of Degradation of Beels of the Hakaluki wetland haor (Source: CNRS [11] and Khan [12])

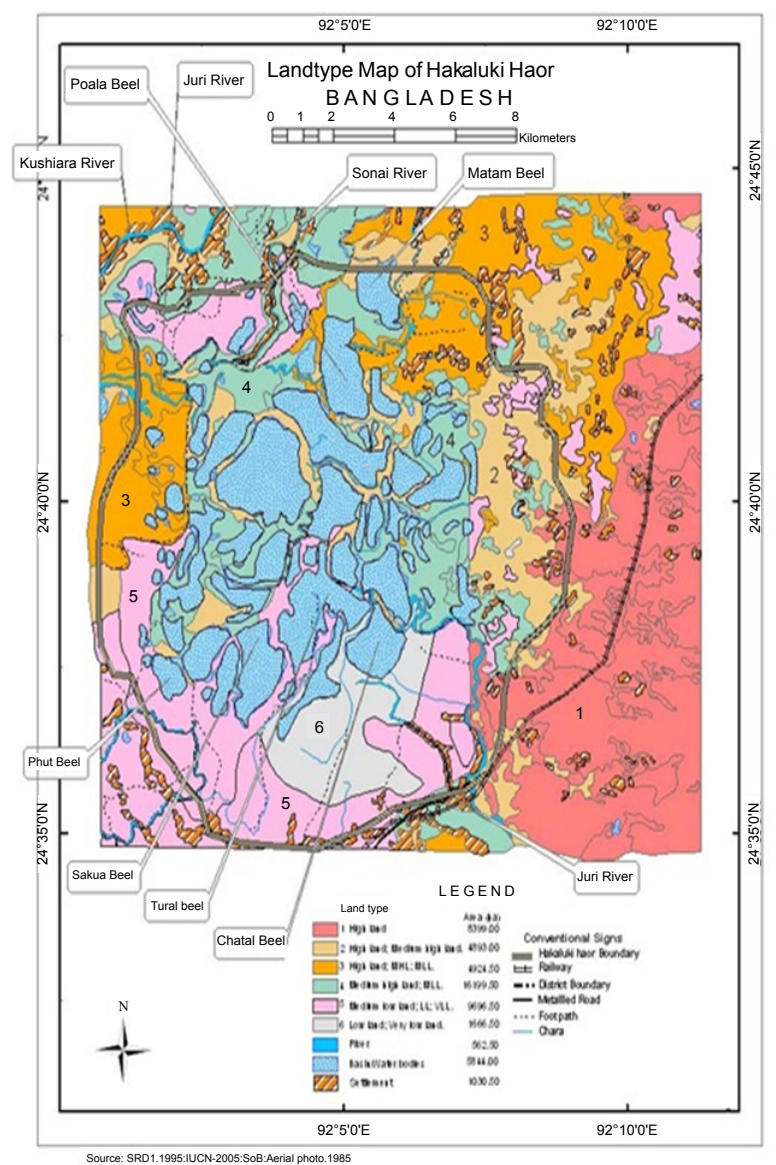

Figure 2: Landtype Map of Hakaluki Wetland Haor

that sedimentation have taken place in low lying areas where grazing lands emerge in course of time.

The basin soil resource of the study sites is Balaganj soil series (Aeric endoaquepts), Goainghat soil series(Typic endoaquepts), Phagu soil series (Typic endoaquepts) Terchibari soil series (Typic endoaquepts) and Hakaluki soil series (Fluvaquantic haplosaprists). The major soil resource of the study site is Hakaluki soil series which consists of poorly to very poorly drained, seasonally flooded, and developed in sub-recent mineral and organic materials on the Surma-Kushiyara floodplains. These soils have a grey to very dark grayish brown, friable clay to peaty clay topsoil, very strongly acid, overlaying peat or alternating clay and peaty strata, generally soft and very sticky when wet. The topsoil remains moist for less than 3 months in the dry season, but the peaty subsoil remain wet nearly all the year. The above mentioned soil and land area are being used by transplanted Aman and Boro rice cultivation

depending on the land conditions. Specifically, high yielding Boro rice cultivation has gained popularity due to high yield production in the lowland basin sites. From the soil profile study, it also confirms that due to long term sedimentation, buried horizon have been formed beneath the plow layer (Plate of Profile view). Thus, the Boro paddy areas have extended in the past 30 pears, considerably reducing the area formerly under grassland and reed swamp.

\section{Conclusion}

From the time series data analysis by GIS technology, it is confirmed that wetland ecosystems of Hakaluki haor is decreasing in course of time due to sedimentation, irregular rainfall and other related anthropogenic causes. This decreasing trend is becoming serious due to the lack proper management planning. Henceforth, this wetland eco-system is degrading seriously which impacts on the bio-resources and biodiversity of the study areas. A sustainable technology should be adopted to prevent the degradation of hilly lands and conservation and caring of soil resources in the wetland basins.

\section{References}

1. IUCN Bangladesh (2005) Hydro-meteorological characteristics of Hakaluki Haor. IUCN Bangladesh Country Office, Dhaka, Bangladesh 10: 91.

2. Morgan JP, McIntire WG (1959) Quaternary geology of Bengal Basin. East Pakistan and India Bull Geo Soc Am 70: 330.

3. World Resource Institute (1990) Centre for international development and environment: Bangladesh Environment and Natural Resource Assessment. Draft Report. Washington DC, USA 86.

4. Haque MI (2008) Water resources management in Bangladesh. Charu Ferdousi Naima for Anushilan Dhaka 218-245.

5. http://www.nishorgo.org/

6. IUCN Bangladesh (2005) Approaches to sustainable wetland resource management. IUCN Bangladesh Country Office, Dhaka, Bangladesh 10: 88.

7. ESRI (1990) ARC/INFO Methods. ESRI, California, USA

8. Hoq MM, Shoaib JU (2003) Edaphological change due to sediment: A case study in Savar Area. J Asiat Soc Bangladesh Sci 29: 27-36.

9. FAO-UNDP (1988) Land resources appraisal of Bangladesh for agricultura development. Report no 2. Agro-ecological regions of Bangladesh. BGD/81/035. FAO, Rome 570.

10. SRDI (1985) Land and soil resource utilization guides. Ministry of Agriculture, Bangladesh.

11. CNRS (2002) Bio-physical and socio-economic characterization of Hakaluk haor: steps towards building community consensus on sustainable wetland resources management. IUCN-Netherlands small grants for wetlands programme, Dhaka, Bangladesh.

12. Khan SMMH (2012) Participatory wetland resource Governance in Bangladesh: An analysis of community based experiments in Hakaluki haor. Ph.D thesis. The University of Manitoba. Natural Resource Institute. Canada.

13. Uddin MJ, Mohiuddin ASM, Hossain ST (2011) Eco-environmental changes in Hail haor wetland resources under Sylhet basin of Bangladesh due to sedimentation: A GIS Approach. Proceedings of the International Conference on 'Environmental Aspects of Bangladesh' (ICEAB11). University of Kitakyushu, Japan.

14. Sultana MS, Islam GMT, Islam Z (2009) Application of geoinformatics in Identifying reduction of wetlands in Dhaka. Ban J Water Resources Research. 21:17-28.

15. Erickson NJ, Ahmed QK, Chowdhury AR (1993) Socio-economic Implications of climate change for Bangladesh. Bangladesh Unnayan Parishad. Dhaka 37.

16. Ullah MS, Uddin MJ, Elahi SF (2006) Changes in spatial patterns of land and soil resources at Mithamoin Upazila under Sylhet Basin of Bangladesh. Dhaka University J Biol Sci 15: 105-111. 